\title{
Jawność zewnętrzna postępowania przygotowawczego na tle art. 12 ustawy Prawo o prokuraturze
}

\begin{abstract}
The aim of the following article is to discuss the issues of the power of the prosecutor to reveal information pertaining to ongoing preparatory proceedings in the light of the new regulations determined by Article 12 of the Act of January 28, 2016, the Law on the Prosecutor's Office. The aforementioned regulation constitutes an important exception to the general rule of confidentiality of preparatory proceedings, which heavily informs the scope of the analysis. Moreover, the author discusses the relationship between Article 12 of the Law on the Prosecutor's Office and earlier regulations regarding the revealing of information regarding preparatory proceedings included in the following acts: press law, law on access to public information, personal data protection act, supplemented with relevant regulations of the Criminal Code and Code of Criminal Procedure. In addition, the author discusses the consequences of the analyzed regulation for the interest of the criminal justice system, the interest of the public, as well as the interest of the parties in the proceedings, which has allowed her to assess the justification for that regulation and the necessity of implementing it in Polish legal system.
\end{abstract}

Key words: preparatory proceedings, prosecutor, duty of confidentiality, right of access to information

Celem niniejszego opracowania jest omówienie zmian $\mathrm{w}$ zakresie ujawniania informacji o toczącym się postępowaniu przygotowawczym, jakie niesie za sobą uchwalenie ustawy Prawo o prokuraturze ${ }^{1}$, która znacząco rozszerza zakres wiadomości, jakie może przekazać prokurator. Nie znajdując swego odpowiednika w poprzednio obowiązującej ustawie, art. 12 ustawy Prawo o prokuraturze stanowi novum w polskim porządku

${ }^{1}$ Ustawa z dnia 28 stycznia 2016 r. Prawo o prokuraturze, Dz.U. 2016, poz. 177. 
prawnym. Ze względu na bardzo nieprecyzyjne i niejasne brzmienie powinien stać się on przedmiotem szczególnego zainteresowania. Ramy niniejszego opracowania nie pozwalają na wszechstronną analizę wskazanego przepisu, dlatego dalsze rozważania skoncentrowano przede wszystkim na ocenie przewidzianych nim unormowań z perspektywy zasady tajności postępowania przygotowawczego oraz na wskazaniu podstawowych zagrożeń, jakie wyłaniają się na jego tle.

Jedną z podstawowych zasad współczesnego procesu karnego jest zasada jawności. Wskazuje na to wyraźne jej uregulowanie, zarówno w aktach prawa międzynarodowego ${ }^{2}$, jak i krajowego. Art. 45 ust. 1 Konstytucji RP gwarantuje każdemu prawo do sprawiedliwego i jawnego rozpatrzenia jego sprawy. Mówiąc o zasadzie jawności, należy jednak mieć na uwadze jej dwoisty charakter. Otóż w doktrynie przyjmuje się, iż na zasadę jawności składają się dwa aspekty ${ }^{3}$ - jawność zewnętrzna, zwana niekiedy zasadą publiczności, oraz jawność wewnętrzna, inaczej określana jako jawność wobec stron ${ }^{4}$.

Jawność zewnętrzna to dyrektywa, w myśl której sprawa powinna być rozpatrzona jawnie wobec osób postronnych, to znaczy w sposób publiczny i umożliwiający udział każdej zainteresowanej osobie. Gwarantuje ona zatem uczestnictwo w czynnościach procesowych bliżej nieskonkretyzowanemu kręgowi podmiotów, pozwalając tym samym na społeczną kontrolę działań podejmowanych przez organy procesowe.

Jawność wewnętrzna natomiast wiąże się z dopuszczeniem do rozpoznania sprawy stron i ich przedstawicieli, jako osób, które są bezpośrednio zainteresowane rozstrzygnięciem ${ }^{5}$. Dyrektywa ta jest realizowana także poprzez stworzenie możliwości zapoznania się z materiałami zgromadzonymi w toku postępowania przez zainteresowane podmioty. W literaturze wskazuje się na ścisłe związki zasady jawności wewnętrznej z zasadami: kontradyktoryjności, prawa do obrony, równości broni, a nawet prawdy materialnej ${ }^{6}$.

Zasada jawności (w obu aspektach) jest na poszczególnych etapach postępowania realizowana z różnym natężeniem. Nie każdy etap procesu musi bowiem charakteryzować się takim samym stopniem otwarcia, do-

${ }^{2}$ Zob. art. 6 ust. 1 Konwencji o Ochronie Praw Człowieka i Podstawowych Wolności z dnia 4 listopada 1950 r., Dz.U. 1994, nr 61, poz. 284 ze zm.; por. także: art. 14 ust. 1 Międzynarodowego Paktu Praw Obywatelskich i Politycznych z dnia 19 grudnia 1966 r., Dz.U. 1977, nr 38, poz. 167.

${ }^{3}$ K. ZgryzeK. W: System prawa karnego procesowego. T. III. Cz. 1: Zasady procesu karnego. Red. P. WiLIŃski. Warszawa 2014, s. 789 i nast.

${ }^{4}$ B. BiEŃKowsKa. W: Wykład prawa karnego procesowego. Red. P. KruszyŃsKi. Białystok 2012, s. 77.

${ }^{5}$ K. Marszat. Proces karny: zagadnienia ogólne. Katowice 2013, s. 119-120.

${ }^{6}$ P. Kardas. W: Jawność jako wymóg rzetelnego procesu karnego. Warszawa 2013, s. 17. 
stępności stron, jak i osób postronnych. Decydujące znaczenie ma tutaj cel, jaki dane stadium procesu powinno realizować ${ }^{7}$. I tak postępowanie przygotowawcze, którego celem jest przede wszystkim ustalenie, czy doszło do popełnienia czynu zabronionego, wykrycie i w razie potrzeby ujęcie sprawcy, wyjaśnienie okoliczności sprawy oraz zebranie, zabezpieczenie i utrwalenie dowodów (art. 297 k.p.k.), cechować musi się przede wszystkim sprawnością i skutecznością podejmowanych działań wykrywczych, co uzależnione jest od warunków, jakie zostaną zapewnione organom ścigania. Jak się wydaje, nie ma tutaj miejsca na udział publiczności, a pierwszeństwo należy przyznać dobru wymiaru sprawiedliwości, co $\mathrm{w}$ szerszej perspektywie pozostaje także $\mathrm{w}$ interesie społeczeństwa - pozwala bowiem skuteczniej reagować na naruszenia prawa. Jawność zewnętrzna tego stadium procesu mogłaby znacząco utrudnić lub nawet uniemożliwić utrwalenie śladów i dowodów przestępstwa, „spłoszyć” niewykrytego jeszcze sprawcę czynu ${ }^{8}$. Podnosi się również, że ujawnienie zbyt wielu informacji może odkryć kolejne planowane dopiero czynności śledztwa czy dochodzenia, a tym samym zniweczyć ich przydatność dla osiągnięcia celów pierwszego stadium procesowego. Stawiałoby to, jak się wydaje, w zbyt uprzywilejowanej pozycji podejrzanego, który zyskiwałby czas, by np. zapewnić sobie fałszywe alibi, zniszczyć dowód przestępstwa czy wpłynąć na zeznania świadków ${ }^{9}$. Prowadzi to wprost do wniosku, iż $\mathrm{w}$ przygotowawczym stadium procesu karnego powinna dominować zasada tajności postępowania, natomiast jawność zewnętrzna nie znajdzie zasadniczo urzeczywistnienia.

Taka konkluzja wydaje się w pełni uzasadniona w świetle standardów konstytucyjnych oraz przepisów ustawy karnoprocesowej, z których wynika wymóg zagwarantowania jawności postępowania sądowego (tak: art. 45 Konstytucji RP, jak również art. 355 k.p.k.). Nie przesądza to automatycznie o tajności postępowania przygotowawczego, jednakże nie należy tracić z pola widzenia art. 241 k.k. oraz art. 102 ustawy Prawo o prokuraturze. Kodeks karny przewiduje w powołanym przepisie typizację czynu zabronionego, polegającego na publicznym rozpowszechnianiu bez zezwolenia wiadomości z postępowania przygotowawczego przed ich ujawnieniem $\mathrm{w}$ postępowaniu sądowym. Czyn ten jest zagrożony grzywną, karą ograniczenia wolności albo pozbawienia wolności do lat 2. Karalność rozpowszechniania informacji z postępowania przygotowawczego wyłączyć może jedynie uzyskanie zezwolenia, a to uznać należy za wyjątek od generalnego zakazu ujawniania treści dotyczących przedsądo-

${ }^{7}$ K. ZgryzeK. W: System prawa karnego procesowego..., s. 801-802.

${ }^{8}$ M. SZERER: Kultura i prawo. Warszawa 1981, s. 207.

9 B. BIEŃKowsKa: Kilka uwag o jawności zewnętrznej postępowania przygotowawczego. PS 1990, nr 7-9, s. 153. 
wej fazy postępowania. Nałożenie na prokuratora obowiązku zachowania tajemnicy służbowej (art. 102 ustawy Prawo o prokuraturze) jest przejawem analogicznych założeń legislacyjnych, przewidujących zasadniczo tajność postępowania przygotowawczego.

$\mathrm{Na}$ tle powyższych spostrzeżeń warto podkreślić jednoznacznie, że założenie tajności postępowania przygotowawczego nie jest i nie powinno być pomyślane $\mathrm{w}$ sposób absolutny, niedopuszczający żadnych odchyleń w zakresie jego realizacji. Nie brakuje wszakże argumentów podkreślających pozytywną stronę jawności zewnętrznej tego stadium procesu. Przede wszystkim w dobie dzisiejszej technologii nie da się zapewnić całkowitej hermetyczności śledztwa. Pewne informacje, czy nawet ich „strzępki”, docierają do opinii publicznej niezależnie od zachowania organów ścigania. Często są to informacje półprawdziwe czy nawet nieprawdziwe, przynoszące z pewnością więcej szkody niż pożytku. Pojawia się więc pytanie, czy nie lepiej - skoro pewne jest, że tzw. przecieków nie da się uniknąć przekazywać jednak w sposób ostrożny i odpowiedzialny pewne wiadomości o toczącym się postępowaniu, by uniknąć spekulacji i sensacyjnych doniesień często mijających się z prawdą. Informacja prawdziwa i rzetelna z pewnością lepiej przysłuży się społeczeństwu. Godny uwagi jest także argument M. Siewierskiego, który w ukrywaniu wszelkich informacji o popełnionych przestępstwach widzi zagrożenie stworzenia pozoru tuszowania niektórych czynów i tym samym wzbudzenia większego niepokoju społecznego ${ }^{10}$. Warto także zaznaczyć, że częściowe upublicznienie postępowania może skłonić społeczeństwo do współpracy z organami ścigania, co natomiast może skutkować szybszym wykryciem i ujęciem sprawcy, a także zmotywować osoby będące w posiadaniu jakichkolwiek informacji lub dowodów do ich ujawnienia ${ }^{11}$. Nie sposób też nie zauważyć, iż w pewnych sprawach przekazanie określonych informacji jest nawet wskazane $\mathrm{w}$ celach prewencyjnych - by ostrzec społeczeństwo przed określonym sprawcą lub przed określonymi czynami zabronionymi.

W aspekcie rozważanej problematyki wspomnieć wypada jeszcze o instytucjach, z którymi łączy się nieuchronnie udzielanie określonych informacji z postępowania przygotowawczego osobom niebędącym stronami procesowymi. Do takich instytucji należą: 1) list gończy (art. 279280 k.p.k.); 2) obowiązek poinformowania przełożonych o wszczęciu $\mathrm{z}$ urzędu postępowania przeciw funkcjonariuszom publicznym, uczniom i żołnierzom (art. 21 k.p.k.); 3) obowiązek poinformowania osoby najbliższej dla oskarżonego o zastosowanym tymczasowym aresztowaniu (art. 261 k.p.k.); 4) obecność świadków przybranych przy przeszukaniu

10 M. SiewIERSKI: Prasa a postępowanie karne. PiP 1962, nr 4, s. 457.

11 B. BieŃKOwsKa: Kilka uwag o jawności zewnętrznej..., s. 153-154. 
(art. 224 k.p.k.). Z uwagi na wąski krąg adresatów oraz lakoniczność przekazywanych informacji w związku z zastosowaniem wymienionych rozwiązań prawnych nie moga być one uznane ani za pełną, ani nawet za częściową realizację zasady jawności zewnętrznej ${ }^{12}$. Niemniej jednak pozwalają świetnie zilustrować sformułowaną wcześniej tezę, iż zasada tajności postępowania przygotowawczego nie jest i nie może być traktowana jako kategoryczny zakaz udzielania jakichkolwiek informacji z tego stadium procesowego.

A zatem skoro postępowanie przygotowawcze nie może realizować zasady jawności zewnętrznej i jednocześnie nie może zakładać całkowitej tajności prowadzonych działań, konieczne jest wskazanie „złotego środka”, pewnego kompromisu ścierających się sprzecznych wartości. Po jednej stronie sytuuje się przede wszystkim interes wymiaru sprawiedliwości, dążenie do sprawnego i skutecznego prowadzenia działań, ale także interes prywatny, wiążący się z zapewnieniem anonimowości uczestników postępowania, a zwłaszcza podejrzanego i pokrzywdzonego, po drugiej zaś - interes społeczny, zainteresowanie obywateli podejmowanymi przez organy ścigania działaniami i potrzeba ich kontrolowania. Na ile wobec tego od zasady tajności postępowania przygotowawczego można odstąpić, w jakim zakresie informacje o toczącym się postępowaniu ujawniać, mając na uwadze przede wszystkim prawo społeczeństwa do informacji, które jest poniekąd gwarancją praworządności? I jak z tej perspektywy przedstawia się unormowanie zawarte w art. 12 ustawy Prawo o prokuraturze?

Poszukiwanie odpowiedzi na te pytania rozpocząć należy od analizy rozwiązań funkcjonujących także przed wejściem w życie ustawy Prawo o prokuraturze, tj. przed dniem 4 marca 2016 r. Kluczowe w tej materii wydają się unormowania kilku ustaw: Prawo prasowe ${ }^{13}$, o dostępie do informacji publicznej ${ }^{14}$, o ochronie danych osobowych ${ }^{15}$, uzupełnione odpowiednimi przepisami Kodeksu karnego i Kodeksu postępowania karnego. Warto już w tym miejscu odnotować, że wymienione wyżej akty prawne nie zostały, w omawianym aspekcie, zmodyfikowane wraz z uchwaleniem ustawy - Prawo o prokuraturze. Należy zatem zastanowić się nad relacją art. 12 ustawy Prawo o prokuraturze do wypracowanych wcześniej, i wciąż aktualnych, rozwiązań.

12 H. Gajewska-KraczkowsKa: Tajność postępowania przygotowawczego a prawo do informacji o jego przebiegu. SP 1990, nr 3, s. 13.

${ }^{13}$ Ustawa z dnia 26 stycznia 1984 r. Prawo prasowe, Dz.U. nr 5, poz. 24 ze zm.

${ }^{14}$ Ustawa z dnia 6 września 2001 r. o dostępie do informacji publicznej, Dz.U. nr 112, poz. 1198 ze zm., określana dalej skrótem u.d.i.p.

${ }^{15}$ Ustawa z dnia 29 sierpnia 1997 r. o ochronie danych osobowych, Dz.U. nr 133, poz. 883 ze zm. 
Generalne uprawnienie obywatela do wiedzy o działalności prokuratury, w tym o przebiegu prowadzonych postępowań, wywodzić można już z art. 61 ust. 1 Konstytucji RP z 1997 r. ${ }^{16}$, bowiem w myśl tego przepisu obywatel ma prawo do uzyskiwania informacji o działalności organów władzy publicznej oraz osób pełniących funkcje publiczne. Natomiast w art. 61 ust. 4 ustawa ta wskazuje, iż ustalenie trybu udzielania informacji należy do materii ustawowej. Dookreślenie konstytucyjnego prawa do informacji znajduje się zatem w ustawie o dostępie do informacji publicznej, która zarazem wspomniane uprawnienie poszerza. $\mathrm{W}$ art. 2 u.d.i.p. posłużono się bowiem określeniem „każdy”, co oznacza, iż ma ona zastosowanie nie tylko do obywateli polskich, ale także cudzoziemców, bezpaństwowców, osób prawnych (w tym z siedzibą za granicą) itd. Ustawa ta wskazuje również przykładowy katalog podmiotów zobowiązanych do udzielania informacji publicznej. Zgodnie z art. 4 ustawy o dostępie do informacji publicznej obowiązek ten spoczywa przede wszystkim na organach władzy publicznej oraz innych podmiotach wykonujących zadania publiczne. W doktrynie i orzecznictwie nie ma sporu co do tego, iż podmiotem takim jest również prokuratura, ze względu na realizację zadań publicznych, jakimi jest strzeżenie praworządności i czuwanie nad ściganiem przestępstw ${ }^{17}$.

Istotne wydaje się zatem pytanie o zakres informacji, jakie podlegają udostępnieniu w trybie ustawy o dostępie do informacji publicznej. Należy w pierwszej kolejności podkreślić, iż prawo do informacji nie jest prawem bezwzględnym i doznaje pewnych ograniczeń. Zgodnie z art. 1 ust. 2 tejże ustawy jej uregulowania nie naruszają przepisów innych ustaw, które odmiennie określają zasady i tryb dostępu do informacji publicznych. Ustawa ta ma być zatem traktowana jako lex generalis, a jej stosowanie może być wyłączone przez przepisy szczególne. Przesłanki ograniczenia prawa do informacji wskazano również w jej art. 5 - są one związane $\mathrm{z}$ ochroną informacji niejawnych i innych tajemnic ustawowo chronionych, z prywatnością osoby fizycznej oraz tajemnicą przedsiębiorcy.

Bez wątpienia w trybie omawianej ustawy udostępniane będą wiadomości dotyczące organizacji wewnętrznej, przedmiotu działalności, kompetencji organów, zasad funkcjonowania, majątku publicznego, naboru kandydatów na poszczególne stanowiska, prowadzonych ewidencji i rejestrów ${ }^{18}$ itp. Odrębną kwestię stanowi natomiast możliwość udostępniania akt postępowania karnego. Zgodnie z ustawą o dostępie do informacji

${ }^{16}$ Dz.U. nr 78, poz. 483.

17 Tak: E. CZARNY-DrożDżEJKo: Funkcjonowanie prokuratury a dostęp do informacji publicznej. Prok. i Pr. 2008, nr 11, s. 82; por. także: I. KamińsKa, M. Rozbicka-OstrowsKa: Ustawa o dostępie do informacji publicznej. Komentarz. Warszawa 2016, s. 93-94.

18 A. JASKUŁA: Uzyskiwanie informacji w postępowaniu przygotowawczym $w$ trybie ustawy o dostępie do informacji publicznych. Prok. i Pr. 2013, nr 2, s. 91. 
publicznej informacją publiczną jest każda informacja o sprawach publicznych (art. 1 ust. 1). Tak skonstruowana definicja nie jest dostatecznie klarowna, uprzedniego wyjaśnienia wymaga więc samo pojęcie „sprawy publicznej”. Można stwierdzić, że w piśmiennictwie do najliczniej reprezentowanych należy szerokie rozumienie tego terminu ${ }^{19}$, zgodnie z którym sprawą publiczną jest każda działalność podmiotu publicznego, łącząca się z wykonywaniem zadań publicznych lub gospodarowaniem majątkiem publicznym. Niewątpliwie prowadzenie akt spraw karnych łączy się z publiczną działalnością prokuratury w zakresie ścigania przestępstw i strzeżenia praworządności. NSA stanął jednak na stanowisku, iż akta spraw karnych nie stanowią w całości informacji publicznej, ponieważ jest to zbiór dokumentów o zróżnicowanym charakterze - urzędowym, prywatnym, wewnętrznym, tajnym - będących nośnikami różnorodnych informacji, w tym informacji publicznych. Nie przesądza to jednak o publicznym charakterze całości akt, dlatego też udostępnieniu w trybie ustawy o dostępie do informacji publicznej będą podlegać tylko konkretne, ściśle wyodrębnione $\mathrm{z}$ akt informacje. Natomiast całość akt spraw karnych będących w toku może być udostępniona jedynie w trybie art. 156 k.p.k., który stosowanie ustawy wyłącza ${ }^{20}$. Można mieć wątpliwości, czy $\mathrm{w}$ istocie art. 156 k.p.k. powinien być traktowany jako lex specialis w stosunku do ustawy o dostępie do informacji publicznej, czy może - skoro akta postępowania karnego jako całość w ogóle nie stanowią informacji publicznej - kwestię ich udostępniania należy rozstrzygnąć bez konieczności sięgania do art. 1 ust. 2 powołanej ustawy. Uwzględniając różnice $\mathrm{w}$ zakresie przedmiotu unormowania ustawy o dostępie do informacji publicznej oraz przedmiotu unormowania art. 156 k.p.k., należy opowiedzieć się za drugim ze wskazanych stanowisk, pozwalającym uznać, że kwestia udostępniania akt postępowania przygotowawczego nie mieści się w zakresie regulacji dostępu do informacji publicznej. Wyczerpującą regulację w tej kwestii zawiera art. 156 \$ k.p.k., wyznaczając jednocześnie krąg osób mogących się z aktami zapoznać (strony, obrońcy, pełnomocnicy, przedstawiciele ustawowi). Tylko w wyjątkowych wypadkach, za zgodą prokuratora, akta mogą być udostępniane innym osobom.

Uwypuklenia wymaga także kwestia możliwości udzielania przez prokuratora informacji dotyczących konkretnych spraw. Jest ona mniej klarowna ze względu na brak wyraźnych uregulowań w zakresie udostępniania tego rodzaju informacji. Należy jednak wziąć pod uwagę przede

19 Tak m.in.: M. BERNACZYK: Obowiazek bezwnioskowego udostęniania informacji publicznej. Warszawa 2008, s. 113 i nast.; I. KamińsKa, M. RozBICKA-OstrowsKa: Ustawa o dostępie..., s. 23-25.

${ }^{20}$ Por. Uchwała 7 sędziów NSA z dnia 9 grudnia 2013 r, I OPS 7/13 oraz wyrok NSA z dnia 28 sierpnia 2015 r., I OSK 1680/14. 
wszystkim art. 102 ustawy Prawo o prokuraturze (pokrywający się $\mathrm{z}$ art. 48 uchylonej ustawy o prokuraturze $\mathrm{e}^{21}$ ), nakładający na prokuratora obowiązek zachowania w tajemnicy okoliczności sprawy, które uzyskał $\mathrm{w}$ toku postępowania przygotowawczego lub poza jawną rozprawą ze względu na sprawowany urząd. W świetle przytoczonego uregulowania ujawnia się bardzo szeroki zakres tajemnicy służbowej prokuratora, który implikuje wyłączenie możliwości ujawnienia nawet ogólnikowych wiadomości dotyczących konkretnych spraw. W sposób naturalny powstaje zatem pytanie: jak wytłumaczyć pojawiające się komunikaty prasowe czy komentarze rzeczników prasowych poszczególnych jednostek prokuratury, w których udziela się informacji o etapie, na jakim jest postępowanie, ujęciu podejrzanego, ogólnym przebiegu zdarzenia?. Oczywiście są to informacje na ogół bardzo lakoniczne, a ich ujawnianie jest ściśle reglamentowane, co zazwyczaj uzasadnia się szeroko rozumianym „dobrem śledztwa". Niemniej jednak stanowią niewątpliwie okoliczności, o jakich mowa w art. 102 ustawy Prawo o prokuraturze. Literalna wykładnia przepisu prowadziłaby do zniweczenia generalnego prawa społeczeństwa do informacji, które jest wyrazem kontroli społecznej i sprzyja transparentności działań organów państwa. Przyjęcie takiej interpretacji musiałoby w konsekwencji oznaczać niespójność rozwiązania przewidzianego $\mathrm{w}$ powołanym przepisie ${ }^{22} \mathrm{z}$ przepisami Prawa prasowego, a także z unormowaniem zawartym w art. 241 k.k. Aby w pełni to uwidocznić, należy podkreślić, że art. 13 Prawa prasowego, choć formułuje ogólny zakaz publikowania danych osobowych i wizerunku osób, przeciwko którym toczy się postępowanie (zarówno przygotowawcze, jak i sądowe), dopuszcza jednak ich ujawnienie za zgodą właściwego prokuratora (w postępowaniu przygotowawczym) lub sądu (w postępowaniu sądowym). W orzecznictwie ${ }^{23}$ przyjmuje się ponadto, iż zakaz przestaje obowiązywać także bez uprzedniego wystąpienia o zgodę prokuratora, jeśli poda on tego typu dane na konferencji publicznej w oficjalnym wystąpieniu, a więc „w warunkach stwarzających podstawę do uznania, iż doszło do uchylenia zakazu, o którym mowa w art. 13 ust. 2 pr.pras." ${ }^{24}$. Taki sam status będzie mieć informacja podana przez rzecznika prasowego prokuratury. Z kolei wspomniany już art. $241 \S 1$ k.k., penalizujący wprawdzie publiczne rozpowszechnianie wiadomości z postępowania przygotowawczego, zanim zostały ujawnione w postępowaniu sądowym, wyraźnie wskazuje, iż chodzi tylko o sytuacje, w których osoba rozpowszechnia-

${ }^{21}$ Ustawa z dnia 20 czerwca 1985 r. o prokuraturze, Dz.U. nr 31, poz. 138.

22 H. Gajewska-KraczKowska: Tajność postępowania..., s. 14.

${ }^{23}$ Zob. wyrok SN z dnia 28 stycznia 2009 r., IV CSK 346/08, a także wyrok SA w Warszawie z dnia 12 stycznia 2012 r., VI Aca 961/11.

${ }^{24}$ Wyrok SN z dnia 29 kwietnia 2011 r., I CSK 509/10. 
jąca informacje nie miała potrzebnego zezwolenia. $\mathrm{Z}$ treści tego przepisu można zatem wywnioskować, iż ujawnianie wiadomości z postępowania przygotowawczego jest możliwe, choć obwarowane koniecznością uzyskania zezwolenia ${ }^{25}$. Nie jest jasne, kto może takiego zezwolenia udzielić. $\mathrm{Na}$ ogół przyjmuje się, iż będzie to jedynie prokurator jako organ procesowy z kierowniczą rolą w postępowaniu przygotowawczym oraz sąd - już po wniesieniu aktu oskarżenia ${ }^{26}$.

Przytoczone uregulowania pozwalają ostatecznie stwierdzić, że wbrew temu, co nasuwa się prima facie na podstawie treści art. 102 ustawy Prawo o prokuraturze, określony w tym przepisie obowiązek zachowania tajemnicy służbowej ma względny charakter. Na tle przedstawionego stanu prawnego przychodzi poddać analizie art. 12 ustawy prawo o prokuraturze, który hołduje koncepcji szerszego dostępu osób postronnych do postępowania przygotowawczego. Przepis art. 12 \$ 1 powołanej ustawy przewiduje uprawnienie Prokuratora Generalnego, Prokuratora Krajowego, a także upoważnionych przez nich prokuratorów do przedstawiania organom władzy publicznej informacji dotyczących działalności prokuratury, w tym konkretnych spraw. W szczególnie uzasadnionych przypadkach wymienione wyżej podmioty będą mogły przekazywać informacje także innym osobom. Już użycie określenia „organy władzy publicznej” w odniesieniu do adresata przekazywanych informacji może budzić uzasadnione wątpliwości. Nie jest to, co prawda, termin obcy polskiemu porządkowi prawnemu, nie posiada jednak definicji legalnej. Terminem tym w kilku przepisach posługuje się Konstytucja RP (art. 7, 163, 228, 238, 239). Z jej treści można wywieść, że do organów władzy publicznej zalicza się także organy samorządu terytorialnego (takie stanowisko akceptuje również orzecznictwo ${ }^{27}$ ). A zatem krąg adresatów informacji przekazywanych przez prokuratora jest dość szeroki, zwłaszcza w kontekście dalszej części art. 12 § 1 ustawy Prawo o prokuraturze, który uprawnia do przedstawiania wiadomości także innym osobom, bez wprowadzenia dodatkowych kryteriów. Mogą to być zatem osoby w żaden sposób niezwiązane $\mathrm{z}$ działalnością $\mathrm{w}$ zakresie ścigania przestępstw czy zapobiegania i zwalczania przestępczości, osoby bez żadnych kompetencji uzasadniających pozyskiwanie takich informacji. Kilku uwag wymaga również zakres

${ }_{25}$ Odmiennie: S. LisIEcKI: Wiadomości z postępowania przygotowawczego pod ochrona. Źródło: http://www.rp.pl/artykul/66440-Wiadomosci-z-postepowania-przygotowawczego-pod-ochrona.html\#ap-1 [dostęp: 02.11.2017].

26 Tak: A. MareK: Kodeks karny. Komentarz. Wyd. V. LEX 2010. Zob. również: J. PiórKowsKA-Flieger: Komentarz do art. 241 Kodeksu karnego. W: Kodeks karny. Komentarz. LEX 2016.

27 Zob. wyrok WSA w Rzeszowie z dnia 13 listopada 2012 r., I SA/Rz 968/12; wyrok WSA we Wrocławiu z dnia 5 marca 2009 r., I SA/Wr 1045/09. 
przedmiotowy art. $12 \S 1$ omawianej ustawy - informacje mogą dotyczyć zarówno działalności prokuratury, jak i konkretnych spraw. Jak zaznaczono wcześniej, możliwość przekazywania wiadomości dotyczących konkretnych spraw karnych nie była dotąd w żadnym przepisie wyrażona wprost. Wniosek, że informacje te będą mogły odnosić się także do treści konkretnych czynności procesowych, nie wydaje się zbyt daleko idący. Niedookreślony pozostaje także zakres podmiotów, których dotyczyć mogą przekazywane informacje - może to być podejrzany, pokrzywdzony lub świadkowie. Ostrożnie do tej pory reglamentowany dostęp do wiadomości z postępowania przygotowawczego niewątpliwie może ulec znacznemu rozszerzeniu. Co prawda $\mathrm{w}$ art. $12 \S 1$ analizowanej ustawy in fine jest mowa o warunku, jaki musi być spełniony, by informacje można było udostępnić - mianowicie muszą one być „istotne dla bezpieczeństwa państwa i jego prawidłowego funkcjonowania”, jednakże trudno oprzeć się wrażeniu, iż jest to sformułowanie zbyt elastyczne, by stanowić mogło rzeczywiste zabezpieczenie przed zbyt pochopnym przekazywaniem informacji istotnych dla toczącego się postępowania karnego. Naturalnie jest dziś jeszcze za wcześnie, by oceniać praktykę stosowania tego artykułu, niemniej jego redakcja jest co najmniej zastanawiająca - głównie ze względu na, w zasadzie, nieograniczony krąg potencjalnych adresatów informacji dotyczących postępowań oraz posłużenie się enigmatyczną klauzulą prawidłowego funkcjonowania państwa. Pozwala to na dużą uznaniowość i w zasadzie arbitralne decyzje prokuratora w kwestii tego, jakie informacje i komu przekazać.

Warto także zwrócić uwagę na art. 12 § 2 ustawy Prawo o prokuraturze, który wyraźnie rozszerza możliwość przekazywania informacji środkom masowego przekazu. Zgodnie z jego treścią uprawnienia takie może uzyskać każdy prokurator. I tutaj, podobnie jak w przypadku art. $12 \S 1$, mowa jest nie tylko o działalności prokuratury, ale również o „informacjach z toczącego się postępowania”. Brak dookreślenia tego pojęcia powoduje, iż przekazana może być właściwie każda informacja. Klauzula ważnego interesu publicznego wzbudza zastrzeżenia analogiczne do tych, jakie wywołuje przewidziany $\mathrm{w}$ art. $12 \S 1$ warunek prawidłowego funkcjonowania państwa. Należy przy tym zauważyć, iż ustawodawca wyłączył jedynie możliwość przekazywania informacji niejawnych. Mając na względzie brak podobnego zastrzeżenia w treści art. $12 \S 1$ ustawy Prawo o prokuraturze, można stwierdzić, że nie jest wykluczone na podstawie tego przepisu przedstawienie organom władzy publicznej i innym osobom informacji niejawnych.

Treść art. 12 § 2 ustawy Prawo o prokuraturze może także nasuwać pytanie o relację tego przepisu do art. 13 ust. 3 i 4 ustawy Prawo prasowe, zgodnie z którymi zgodę na publikowanie wizerunku oraz danych 
osobowych podejrzanego $\mathrm{w}$ toku postępowania przygotowawczego wydaje właściwy prokurator. Wydane $\mathrm{w}$ tym celu postanowienie może być przedmiotem zażalenia do sądu rejonowego, w którego okręgu toczy się postępowanie. Nie jest w pełni jasne, czy unormowanie zawarte w art. 12 $\S 2$ ustawy Prawo o prokuraturze stanowi lex specialis w stosunku do wymienionych przepisów Prawa prasowego, czy też wykorzystanie uprawnienia przewidzianego $\mathrm{w}$ pierwszym ze wskazanych przepisów $\mathrm{w}$ zakresie dotyczącym przekazania informacji zawierających dane osobowe podejrzanego może mieć miejsce dopiero po wydaniu i uprawomocnieniu się określonego wyżej postanowienia. Ma to istotne znaczenie $\mathrm{w}$ aspekcie gwarancji sądowej kontroli decyzji o ujawnianiu danych podejrzanego. Wydaje się, niestety, że na podstawie art. 12 \$ 2 ustawy Prawo o prokuraturze będzie można pominąc tryb przewidziany w Prawie prasowym. Art. 13 ust. 3 Prawa prasowego stanowi bowiem, że zawarty w tym przepisie zakaz publikowania wizerunku i danych osobowych osób, przeciwko którym toczy się postępowanie przygotowawcze, nie narusza przepisów innych ustaw.

Kolejną kwestią, na którą należy zwrócić uwagę w kontekście unormowania przewidzianego w art. 12 ustawy Prawo o prokuraturze, jest tryb udzielania informacji z postępowania przygotowawczego na podstawie tego przepisu. Przepis art. $12 \S 3$ powołanej ustawy przewiduje w tym względzie jedynie, że nie jest wymagane uzyskanie zgody prowadzącego postępowanie przygotowawcze. Nadzorujący postępowanie prokurator zyskuje zatem uprawnienie do udzielenia informacji dotyczących postępowania przygotowawczego prowadzonego przez inny organ. Brak wymogu uzyskania choćby opinii prowadzącego postępowanie może budzić wątpliwości. W świetle tego artykułu możliwe jest więc przekazywanie informacji nawet wbrew woli prokuratora najbardziej zainteresowanego jego przebiegiem, jak i wynikiem. Należałoby się jednak zastanowić, czy nie powinien on zostać przynajmniej poinformowany o planowanym upublicznieniu wiadomości dotyczących postępowania ${ }^{28}$, z uwagi na to, iż jako „gospodarz” przygotowawczego stadium procesu najlepiej wie, jakie informacje w danym momencie mogą być ujawnione bez uszczerbku dla trwającego postępowania.

Analizując art. 12 ustawy Prawo o prokuraturze, nie sposób także pominąć unormowania zawartego $\mathrm{w} \S 4$ tego przepisu, przewidującego wyłączenie jakiejkolwiek odpowiedzialności prokuratora ujawniającego informacje dotyczące postępowania. Za wszelkie roszczenia, jakie pozo-

${ }^{28}$ Wątpliwości w tej kwestii zostały wyrażone w opinii Prokuratora Generalnego do projektu Ustawy Prawo o prokuraturze z dnia 12 stycznia 2016 r. Źródło: http://www. sejm.gov.pl/Sejm8.nsf/druk.xsp?nr=162 [dostęp: 02.11.2017] - zob. s. 8. 
stają w związku z czynnościami opisanymi w poprzednich paragrafach, odpowiedzialność poniesie bowiem Skarb Państwa. Będzie tu wchodzić $\mathrm{w}$ grę przede wszystkim ewentualna odpowiedzialność za naruszenie dóbr osobistych (art. 24 k.c.). Potwierdza to także uzasadnienie do projektu ustawy $^{29}$, z którego wynika, iż Prokurator Generalny lub inny upoważniony przez niego prokurator nie będą ponosili odpowiedzialności cywilnej i majątkowej za przekazanie rzetelnych i zgodnych z poczynionymi ustaleniami informacji. Analizowane unormowanie oznacza wyeliminowanie istotnego czynnika hamującego w postaci odpowiedzialności cywilnej, który z pewnością wymuszałby staranną selekcję informacji z postępowania przygotowawczego, podlegających przekazaniu na podstawie art. 12 $\S 1$ lub $\$ 2$ ustawy Prawo o prokuraturze, oraz oddziaływał powściągająco na prokuratorów $\mathrm{w}$ zakresie wykorzystania przewidzianego $\mathrm{w}$ tych przepisach uprawnienia, gdyby mogło to naruszyć prawa uczestników postępowania lub innych osób. Nie sposób oprzeć się wrażeniu, iż ustawodawca, licząc się z możliwymi negatywnymi dla prokuratora konsekwencjami przekazania informacji z postępowania przygotowawczego w postaci np. pozwu cywilnego, stara się w drodze analizowanego rozwiązania uchronić go przed nimi. Trudno taki stan rzeczy zaakceptować, przede wszystkim dlatego, że poczucie braku odpowiedzialności za działania podejmowane na podstawie art. 12 ustawy Prawo o prokuraturze może stać się przyczyną zbyt swobodnego sięgania przez organy prokuratorskie do uprawnień przewidzianych $\mathrm{w}$ tym przepisie. Całą odpowiedzialność poniesie w takich wypadkach państwo, więc pośrednio obywatele łożący na jego funkcjonowanie zapłacą za pochopne przekazywanie informacji z postępowania przygotowawczego, naruszające prawa uczestników procesu lub osób trzecich.

Co ciekawe, w uzasadnieniu do projektu ustawy Prawo o prokuraturze wskazano także, iż przy przekazywaniu informacji dotyczących postępowania nie znajdzie zastosowania art. $156 \S 5$ k.p.k. ${ }^{30}$. Sugeruje to, iż potrzeba zabezpieczenia prawidłowego toku postępowania, o której mowa $\mathrm{w}$ tym przepisie, nie będzie brana pod uwagę przy stosowaniu art. 12 ustawy Prawo o prokuraturze, który posługuje się innymi kryteriami udostępniania informacji. Prawidłowy tok postępowania jest - co oczywiste - konieczny, by mogło ono osiągnąć wskazane w art. 297 k.p.k. cele. Ich realizacja może być jednak zagrożona, jeśli informację o dokonywanych czynnościach procesowych pozyska zbyt szeroki krąg osób. Konsekwencją może być wówczas działanie polegające na matactwie, ukrycie się osób,

${ }^{29}$ Druk nr 162, poselski projekt ustawy o prokuraturze - Prawo o prokuraturze. Źródło: www.sejm.gov.pl [dostęp: 02.11.2017] - zob. s. 97.

${ }^{30}$ Ibidem, s. 97. 
którym w przyszłości mogłyby zostać postawione zarzuty, zniszczenie lub ukrycie dowodów itp. W tej sytuacji zatem obniżenie efektywności prowadzonych działań jest, niestety, zagrożeniem bardzo realnym. Trudno oczywiście przypuszczać, aby celem prokuratora było dopuszczenie do wskazanych konsekwencji, nie można jednak całkowicie wykluczyć niebezpieczeństwa ich powstania. Wyłączenie stosowania art. 156 § 5 k.p.k. powoduje ponadto, iż nie będzie konieczne wydanie zarządzenia, jak $\mathrm{w}$ przypadku udostępnienia akt, ani uzasadnienie przekazania informacji innym osobom, którego wymagał art. $156 \$ 5$ - akta mogą być bowiem udostępniane jedynie „w wyjątkowych wypadkach”. Art. 12 ustawy Prawo o prokuraturze nie przesądza też o tym, czy informacje mogą być udostępniane jedynie na wniosek zainteresowanych osób czy również $\mathrm{z}$ urzędu.

Uzasadnione jest przypuszczenie, że art. 12 ustawy Prawo o prokuraturze, jako kolejny wyjątek od generalnego obowiązku zachowania w tajemnicy wszelkich okoliczności, o jakich dowiedział się prokurator $\mathrm{w}$ związku z prowadzeniem postępowania przygotowawczego, odstępstwa od zasady tajności postępowania nieco poszerza. Przy czym, mając na uwadze jego ogólnikową i nieprecyzyjną treść, można żywić obawę, że „nieco” zamieni się w „bardzo”. Operowanie nieostrymi pojęciami i przyzwolenie na, w zasadzie arbitralne, ujawnianie informacji mogących także naruszyć prawa uczestników postępowania musi spotkać się z krytyką. Tym bardziej że art. 12 ustawy Prawo o prokuraturze przewiduje także rozszerzenie zakresu informacji, jakie o toczącym się postępowaniu mogą uzyskać media. Negatywną konsekwencją udziału mediów w fazie przygotowawczej postępowania jest z pewnością możliwość wytworzenia pewnej medialnej formy nacisku na organy ścigania $w$ drodze doniesień prasowych czy telewizyjnych, wskazujących spodziewane działania czy rozstrzygnięcia i poddających krytyce ich brak. Jest to także istotne z perspektywy jednej z naczelnych zasad procesu karnego, mianowicie zasady domniemania niewinności. Aspekt zewnętrzny tej zasady znajduje wyraz w obowiązku traktowania oskarżonego jako niewinnego, dopóki jego wina nie zostanie stwierdzona prawomocnym wyrokiem przez każdą osobę, instytucję czy organizację. Dotyczy to także wydawnictw prasowych i pozostałych środków masowego przekazu ${ }^{31}$. Choć art. 13 ust. 1 Prawa prasowego zakazuje wydawania opinii co do rozstrzygnięcia postępowania karnego przed wydaniem wyroku w I instancji, można wątpić w jego skuteczność. Jest to klasyczny przykład lex imperfecta, bowiem Prawo prasowe nie przewiduje żadnych sankcji za naruszenie owego zakazu. Jedyne środki, jakie mogą zapewnić ochronę, to prawo żądania opublikowania

31 K. MarszaŁ: Proces karny..., s. 133-134. 
sprostowania lub odpowiedzi w prasie (art. 31), powództwo o ochronę dóbr osobistych lub postępowanie dyscyplinarne przed sądem dziennikarskim $^{32}$. Nie zapobiegają one jednak naruszeniom, lecz tylko łagodzą ich skutki, które często pozostają nieodwracalne. Niebezpieczeństwo potencjalnych naruszeń interesu prywatnego uczestników postępowania, przejawiające się nie tylko w naruszeniu dóbr osobistych podejrzanego, ale także pogwałceniu prawa do prywatności pokrzywdzonego, ulega z całą pewnością zwiększeniu wraz z rozszerzeniem możliwości przekazywania informacji z postępowania przygotowawczego na podstawie art. 12 ustawy Prawo o prokuraturze.

Również interes wymiaru sprawiedliwości może doznać na gruncie art. $12 \S 2$ ustawy Prawo o prokuraturze pewnego uszczerbku. Niebezpieczeństwo zwiększenia „przecieków” z postępowania przygotowawczego nie przysłuży się jego celom, przeciwnie - może w sposób zdecydowanie negatywny oddziaływać na skuteczność prowadzonych działań.

$\mathrm{Z}$ drugiej strony nie można tracić z pola widzenia pewnych korzyści, jakie łączą się z rozszerzeniem możliwości udzielenia informacji dotyczących konkretnych postępowań. Można sądzić, że pozwoli to na efektywniejszą kontrolę społeczną działań organów ścigania karnego, być może wyeliminowanie ich opieszałości, a także zwiększenie przejrzystości tych działań, a w rezultacie zwiększenie zaufania społeczeństwa do organów odpowiedzialnych za zapobieganie i zwalczanie przestępczości.

Niewątpliwie korzyści płynące ze zwiększenia udziału społeczeństwa i mediów w postępowaniu przygotowawczym tracą jednak na znaczeniu w porównaniu z zagrożeniami, jakie się jednocześnie stwarza. Art. 12 ustawy Prawo o prokuraturze zdaje się nadawać prymat interesowi społecznemu, powodując jednocześnie ryzyko naruszenia interesu prywatnego oraz interesu wymiaru sprawiedliwości. Nieprecyzyjne brzmienie przepisu stwarza dość duże pole do nadużyć, co nie może być akceptowane w warunkach demokratycznego państwa prawa - szczególnie, że działania podejmowane na podstawie tego artykułu mogą znacząco ingerować w sferę konstytucyjnie zagwarantowanych praw jednostki. Dlatego też należałoby postulować gruntowne przeredagowanie art. 12 ustawy Prawo o prokuraturze, polegające przede wszystkim na ograniczeniu kręgu podmiotów, którym mogą być przekazywane informacje dotyczące konkretnych spraw zarejestrowanych w jednostkach prokuratury, oraz uściśleniu przesłanek udostępniania tych informacji. Nie wydaje się bowiem, by omawiany przepis $\mathrm{w}$ wystarczającym stopniu uwzględniał interes uczestników postępowania, a także interes wymiaru sprawiedliwości, a co za tym idzie - by był dla polskiego porządku prawnego korzystny.

32 S. Waltoś: Prasa i proces karny. „Zeszyty Prasoznawcze” 1986, nr 1, s. 16. 


\section{Bibliografia}

\section{Literatura}

BERNACZYK M.: Obowiązek bezwnioskowego udostępniania informacji publicznej. Warszawa 2008.

BIEŃKOWsKa B.: Kilka uwag o jawności zewnętrznej postępowania przygotowawczego. PS 1990, nr 7-9.

CZARnY-DrożDżejKo E.: Funkcjonowanie prokuratury a dostęp do informacji publicznej. Prok. i Pr. 2008, nr 11.

Gajewska-Kraczkowska H.: Tajność postępowania przygotowawczego a prawo do informacji o jego przebiegu. SP 1990, nr 3.

JASKUŁA A.: Uzyskiwanie informacji $w$ postępowaniu przygotowawczym $w$ trybie ustawy o dostępie do informacji publicznych. Prok. i Pr. 2013, nr 2.

KamińsKa I., Rozbicka-OstrowsKa M.: Ustawa o dostępie do informacji publicznej. Komentarz. Warszawa 2016.

KARDAS P. W: Jawność jako wymóg rzetelnego procesu karnego. Warszawa 2013.

MarszaŁ K.: Proces karny: zagadnienia ogólne. Katowice 2013.

SIEWIERSKI M.: Prasa a postępowanie karne. PiP 1962, nr 4.

Szerer M.: Kultura i prawo. Warszawa 1981.

System prawa karnego procesowego, T. III. Cz. 1: Zasady procesu karnego. Red. P. WILIŃsKI. Warszawa 2014.

Waltoś S.: Prasa i proces karny. „Zeszyty Prasoznawcze” 1986, nr 1.

Wykład prawa karnego procesowego. Red. P. Kruszyński. Białystok 2012.

\section{Orzecznictwo}

Wyrok SN z dnia 28 stycznia 2009 r., IV CSK 346/08.

Wyrok SN z dnia 29 kwietnia 2011 r., I CSK 509/10.

Uchwała 7 sędziów NSA z dnia 9 grudnia 2013 r., I OPS 7/13.

Wyrok NSA z dnia 28 sierpnia 2015 r., I OSK 1680/14.

Wyrok WSA we Wrocławiu z dnia 5 marca 2009 r., I SA/Wr 1045/09.

Wyrok WSA w Rzeszowie z dnia 13 listopada 2012 r., I SA/Rz 968/12.

Wyrok SA w Warszawie z dnia 12 stycznia 2012 r., VI Aca 961/11. 